\title{
An Analysis of the Distribution, Ecology, and Status of Bugseeds (Corispermum) in Canada
}

\author{
DiANA BIZECKI RoBSON
}

The Manitoba Museum, 190 Rupert Avenue, Winnipeg, Manitoba R3B 0N2 Canada; e-mail: drobson@manitobamuseum.ca

Robson, Diana Bizecki. 2010. An analysis of the distribution, ecology, and status of bugseeds (Corispermum) in Canada. Canadian Field-Naturalist 124(3): 246-255.

The bugseeds (Corispermum spp.) are a genus of annual plants that are uncommon due to their psammophilic, ruderal habit. Bugseeds are typically found in natural areas with some bare sand, like sand dunes, but are also present in anthropogenically impacted sandy or gravelly areas. Increasing dune stabilization may be causing the endangerment of some Bugseed species. Assessing the rarity of the five species in Canada is hindered by the lack of recently collected specimens and the use of out-dated nomenclature in herbaria. Specimens of bugseeds from major herbaria all across Canada were examined and re-identified using the most recent taxonomic treatment in the Flora of North America. Hairy Bugseed (C. villosum) was the most commonly collected taxon and Hooker's Bugseed (C. hookeri var. pseudodeclinatum) the rarest. The natural distribution of all taxa, except Alaskan Bugseed (C. ochotense) which is only found in the far north, is from British Columbia to Ontario. Hairy, Hooker's and American Bugseed (C. americanum) are also found in Quebec, where they may have been introduced from further west. Summaries of Bugseed localities and habitats, and distribution maps are presented to facilitate the status assessment of plants in this genus.

Key Words: bugseeds, Corispermum, distribution, habitat, psammophile, status, Canada.

The bugseeds (Corispermum spp.) are a genus of annual plants that favour sandy and gravelly glaciofluvial soils (Welsh et al. 2003). Initial taxonomic treatments and floras considered there to be only three species of European-introduced Corispermum in all of North America, namely C. hyssopifolium L., C. nitidum Kit. and $C$. orientale Lam (Maihle and Blackwell 1978). However, recent research on the genus, including palaeobotanical evidence (Betancourt et al. 1984; Matthews et al. 1990), suggests that most of the species found in North America are native and unrelated to European flora, sharing a closer affinity with eastern Asian species (Mosyakin 1995). In fact, two species found in Canada, Alaskan Bugseed (C. ochotense Ignatov) and Pallas Bugseed (C. pallasii Steven) are now recognized as being native in eastern Asia as well as North America (Mosyakin 1995; Welsh et al. 2003). Three additional species found in Canada, Hooker's Bugseed (C. hookeri Mosyakin), American Bugseed (C. americanum (Nuttall) Nuttall) and Hairy Bugseed (C. villosum Rydberg), are considered to be native to North America, with the former one being endemic to Canada (Welsh et al. 2003). Thus the original scientific names that Canadian Corispermum specimens were assigned are now incorrect. Due to a lack of resources many regional herbaria in Canada had not completely updated the nomenclature of their Bugseed specimens; a mixture of old and new names were being used. This in turn made assessment of the status of these species difficult since only a limited number of specimens were identified correctly.

To facilitate status assessment I examined Bugseed specimens from all major herbaria in Canada and re- identified them to the most recent nomenclature. This article summarizes the distribution, habitat and status of the Bugseed genus in Canada.

\section{Methods}

Herbarium specimens from 20 herbaria in Canada (see Acknowledgments for a complete list) were borrowed and examined. A total of 499 specimens were looked at; of those specimens 267 had already been annotated to the nomenclature in Flora of North America (Welsh et al. 2003) by nine different botanists, mostly S. Mosyakin, author of the most recent Corispermum taxonomic treatment (Mosyakin 1995), J. Cayouette (Curator at DAO) and V. L. Harms (retired Curator at SASK). I annotated 232 of the specimens that still possessed old synonyms by using the keys and species descriptions in Welsh et al. (2003) and comparing the specimens to those that had been annotated by Mosyakin. Measurements of seeds using callipers were often required to identify the specimens. There were 31 specimens that could not be confidently identified to species as they were too immature. One specimen of Alaskan Bugseed from the Harvard University Herbarium was not actually observed but as the label data was available in Cody et al. (2003), the information was included in this study. Contrary to previous keys (Scoggan 1956, 1978; Looman and Best 1979; Moss 1983), the hairiness of the plants is not a reliable character for distinguishing Bugseed species; it is the shape and dimensions of the fruits and wings, and the density of the inflorescences that are the most important characters (Mosyakin 1995; Sukhorukov 2007). For this reason identification of Bugseed species is 
difficult when the plant is immature as fruits are generally needed for positive identification.

To facilitate the production of summary data and distribution maps, all label information from each specimen was recorded into a spreadsheet. To prepare the distribution maps, a latitude and longitude for each specimen was obtained. Geographic co-ordinates were available for $29 \%$ of the specimens, either obtained directly by the original collector or derived from the label information by the staff at the herbaria housing the specimens. To obtain a latitude and longitude for 14 specimens with a legal land description only, the midpoint of the legal subdivision, quarter or half section, or section was obtained using a geographic conversion website (http://legallandconverter.com). No geographic co-ordinate was supplied by the collector for most specimens $(71 \%)$. For these specimens, the locality name on the label was entered into the Atlas of Canada website (http://atlas.nrcan.gc.ca/site/english/ maps/topo/map) search function and a latitude/longitude for that location recorded. Sometimes detailed locality descriptions (e.g., 5-6 miles east of Mortlach) could be used in conjunction with Atlas of Canada maps to pinpoint a more accurate location than using just a locality name co-ordinate. When multiple place names came up in the search, the locality and habitat description was used to help select the most likely location of the collected specimen. Thus the accuracy of the geographic co-ordinates is only approximate but likely within a $10-25 \mathrm{~km}$ radius. Ground truthing is necessary to confirm the existence of the species at those precise co-ordinates. Nonetheless, the maps give a good general idea of the species' known distributions in Canada.

To prepare the habitat summary, the descriptions recorded by the collector were used to group the habitats into one of three categories: natural areas not directly impacted by humans, anthropogenically impacted areas where humans had disturbed the soil in some manner and specimens with no recorded description. Natural areas were further divided into six categories: (1) riparian sand banks and dunes, (2) riparian sand bars, (3) inland sand dunes and blowouts, (4) inland sandy hills and cliffs, (5) inland sandy plains and (6) lacustrine beaches and dunes. Anthropogenically impacted areas were further divided into six categories: (1) cultivated fields, (2) railways, (3) sand and gravel pits, (4) sandy disturbed areas, (5) sandy fireguards and (6) sandy roadsides.

As the process to rank species is based at least partly on the number of localities (Canadian Endangered Species Conservation Council (CESCC) 2005*; NatureServe 2010*), the results of this study were used to recommend status changes for some taxa. Using the information from this assessment, I prepared suggested ranks using NatureServe (2010*) and CESCC (2005*) numerical codes, for the various species based on locality data (Table 4). Using the NatureServe (2010*) ranks, jurisdictions with fewer than five localities were given a rank of " 1 " or critically imperilled, those with 5 to 15 localities were given a rank of " 2 " or imperilled and those with 15 to 100 localities were given a rank of vulnerable. For the CESCC (2005*) ranks, no taxa were given a rank of " 1 " or "At Risk", as this designation implies that the taxa has already been protected under the Species At Risk Act 2002, or assessed by the Committee on the Status of Endangered Wildlife in Canada (COSEWIC 2010*) or a provincial governing body. Therefore taxa with 15 or fewer localities were given a rank of " 2 " or "May Be At Risk" while those with 16 to 100 localities were given a rank of " 3 " or "Sensitive". All Bugseed species were considered "Sensitive" rather than "Secure" or "Vulnerable" given their presence in habitats that are known to be in decline (Hugenholtz and Wolfe 2005; Robson 2006).

\section{Results}

\section{Distribution and Habitat}

Although 499 herbarium specimens of Canadian bugseeds were examined, they represented only 272 localities as 228 of them appear to be duplicates (Table 1). Some of these locality duplicates were collected by the same person on the same date and distributed to herbaria all across the country, as was typical of collectors such as B. Boivin, H. J. Scoggan, G. Ledingham, R. Giroux, W. J. Cody, W. G. Dore and A. J. Breitung to name a few. The holotype of Hooker's Bugseed, which is located at the Department of Agriculture Herbarium (DAO), is one such specimen with isotypes located on nine herbaria in Canada and at least one in the U.S. (only two isotypes were known about when the species description was published by Mosyakin in 1995). Other locality duplicates were collected by two different people on two different dates but had the exact same (but often vague) locality description (e.g., Fort Saskatchewan, Alberta). The two specimens may not have been collected at the exact same location but without additional label information it is impossible to know. At 35 of the localities more than one species of Bugseed was found; at four localities - two in Saskatchewan, one in Alberta and one in Ontario-specimens of four Bugseed species were found.

Bugseed plants occur in eight ecozones from as far north as Aklavik, Northwest Territories south to the shore of Lake Erie, Ontario, and from Vancouver, British Columbia in the west to Quebec City, Quebec in the east. However, the vast majority (52\%) of Bugseed localities are in the Prairie ecozone (Marshall and Schut 1999), which spans Alberta, Saskatchewan and Manitoba (Table 2). An additional $22 \%$ of the localities are in the Boreal Shield and Boreal Plain ecozones, which stretch from Newfoundland to eastern British Columbia. Canadian bugseeds have not been found along oceanic beaches and dunes in the Atlantic Maritime ecozone.

Bugseeds are most common in pioneer, marginal, and naturally and artificially disturbed soils high in sand 
TABLE 1. Number of Bugseed (Corispermum spp.) localities and specimens (in brackets) from Canadian provinces/territories based on an examination of specimens in 20 Canadian herbaria.

\begin{tabular}{|c|c|c|c|c|c|c|c|c|c|}
\hline \multirow[b]{2}{*}{ Species } & \multicolumn{9}{|c|}{$\begin{array}{c}\text { Province/Territory } \\
\text { \# localities (\# specimens) }\end{array}$} \\
\hline & $\mathrm{BC}$ & $\mathrm{AB}$ & SK & MB & $\mathrm{ON}$ & QU & NT & YT & Total \\
\hline $\begin{array}{l}\text { C. americanum } \\
\text { C. hookeri }\end{array}$ & $3(3)$ & $11(15)$ & $15(34)$ & $21(72)$ & $15(21)$ & $7(11)$ & & & $72(156)$ \\
\hline v. hookeri & $6(6)$ & $9(14)$ & $10(24)$ & $1(1)$ & $7(15)$ & & $3(4)$ & & $36(64)$ \\
\hline $\begin{array}{l}\text { v. pseudodeclinatum } \\
\text { C. ochotense }\end{array}$ & $2(3)$ & & & & & & & & $2(3)$ \\
\hline v. ochotense & & & $1(2)$ & & & & $6(11)$ & & $7(13)$ \\
\hline v. alaskanum & & & & & & & & $1(1)$ & $1(1)$ \\
\hline C. pallasii & $4(4)$ & $9(19)$ & $17(33)$ & $3(11)$ & $9(14)$ & $4(5)$ & & & $46(86)$ \\
\hline C. villosum & $7(7)$ & $18(39)$ & $28(39)$ & $9(13)$ & $12(23)$ & $3(14)$ & $1(11)$ & & $78(146)$ \\
\hline Corispermum sp. & $6(6)$ & $3(4)$ & $7(7)$ & $4(5)$ & $8(8)$ & & $1(1)$ & & 29(31) \\
\hline Total & $28(29)$ & $50(91)$ & $78(139)$ & $38(102)$ & $52(81)$ & $14(30)$ & $11(27)$ & $1(1)$ & $272(500)$ \\
\hline
\end{tabular}

TABLE 2. Ecozones where Bugseed (Corispermum spp.) localities in Canada occur.

\begin{tabular}{|c|c|c|c|c|c|c|c|}
\hline \multirow[b]{2}{*}{ Ecozone } & \multicolumn{7}{|c|}{$\begin{array}{c}\text { Species } \\
\text { \# localities }\end{array}$} \\
\hline & C. americanum & C. hookeri & C. ochotense & C. pallasii & C. villosum & C. sp. & Total \\
\hline Prairie & 42 & 19 & & 24 & 45 & 11 & 141 \\
\hline Boreal Shield & 17 & 1 & 1 & 4 & 10 & 3 & 36 \\
\hline Mixedwood Plains & 5 & 8 & & 6 & 6 & 6 & 31 \\
\hline Boreal Plains & 6 & & & 8 & 8 & 1 & 23 \\
\hline Montane Cordillera & 1 & 3 & & 3 & 6 & 6 & 19 \\
\hline Taiga Plains & & 3 & 6 & & 1 & 1 & 11 \\
\hline Pacific Maritime & & 5 & & 1 & 1 & 1 & 8 \\
\hline Boreal Cordillera & 1 & & 1 & & 1 & & 3 \\
\hline
\end{tabular}

and gravel (Mosyakin 1995) (Figure 1). Most specimens $(55 \%)$ came from natural areas but $30 \%$ came from anthropogenically impacted areas; $15 \%$ had no habitat description (Table 3). Of the natural areas, the most commonly cited habitat was inland sand dunes and blowouts including the Battle River, Beaver Hill, Buffalo Park, Fish Lake, Edson and Middle Sand Hills of Alberta, the Athabasca, Dundurn, Elbow, Great, Pelican Lake and Seward Sand Hills of Saskatchewan, and the Routledge and Brandon Sand Hills of Manitoba. Lacustrine beaches and dunes along Lakes Huron, Erie and Superior in Ontario, and Lakes Manitoba and Winnipeg in Manitoba were the next most common habitat. Riparian sand banks and dunes along the Mackenzie River in the Northwest Territories, the Laird and Fraser Rivers in British Columbia, the Saskatchewan, Frenchman and Qu'appelle Rivers in Saskatchewan, the Athabasca, Elbow, Red Deer and Saskatchewan rivers in Alberta, and the St. Lawrence River in Quebec are also the location of many Bugseed populations. Sandy roadsides, railways, and other disturbed sandy areas like landfills and parking lots are the most common anthropogenically impacted habitats of bugseeds.

The Alaskan Bugseed (C. ochotense) is the northernmost species: var. ochotense Ignatov was found along the Mackenzie River Valley of the Northwest Territories and var. alaskanum Mosyakin near Kluane Lake in the Yukon. This species also occurs in Alaska and eastern Russia (Mosyakin 1995). Specimens of Alaskan Bugseed that were transitional to Hairy Bugseed in growth form (i.e. taller than those specimens further north) were found on the Athabasca Sand Dunes (Figure 2) in northern Saskatchewan (Welsh et al. 2003).

Hairy Bugseed (C. villosum) is the most common and widespread species in Canada occurring as far south as the Great Lakes and as far north as the Mackenzie River Valley in Northwest Territories (Figure 3). Plants of this species occur in sandy habitats in seven provinces/ territories across eight different ecozones. Hairy Bugseed is also found in ten northern U.S. states but its distribution is disjunct (NatureServe 2010*); this could be due to the lack of accurate species identifications in regional U.S. herbaria.

American Bugseed (C. americanum var. americanum) has a similar distribution as Hairy Bugseed although it has not been found in the Northwest Territories, nor as far west as the latter species (Figure 4). However, its eastern limit extends right to the mouth of the St. Lawrence River in Quebec. It was found in six ecozones in southern Canada. American Bugseed 


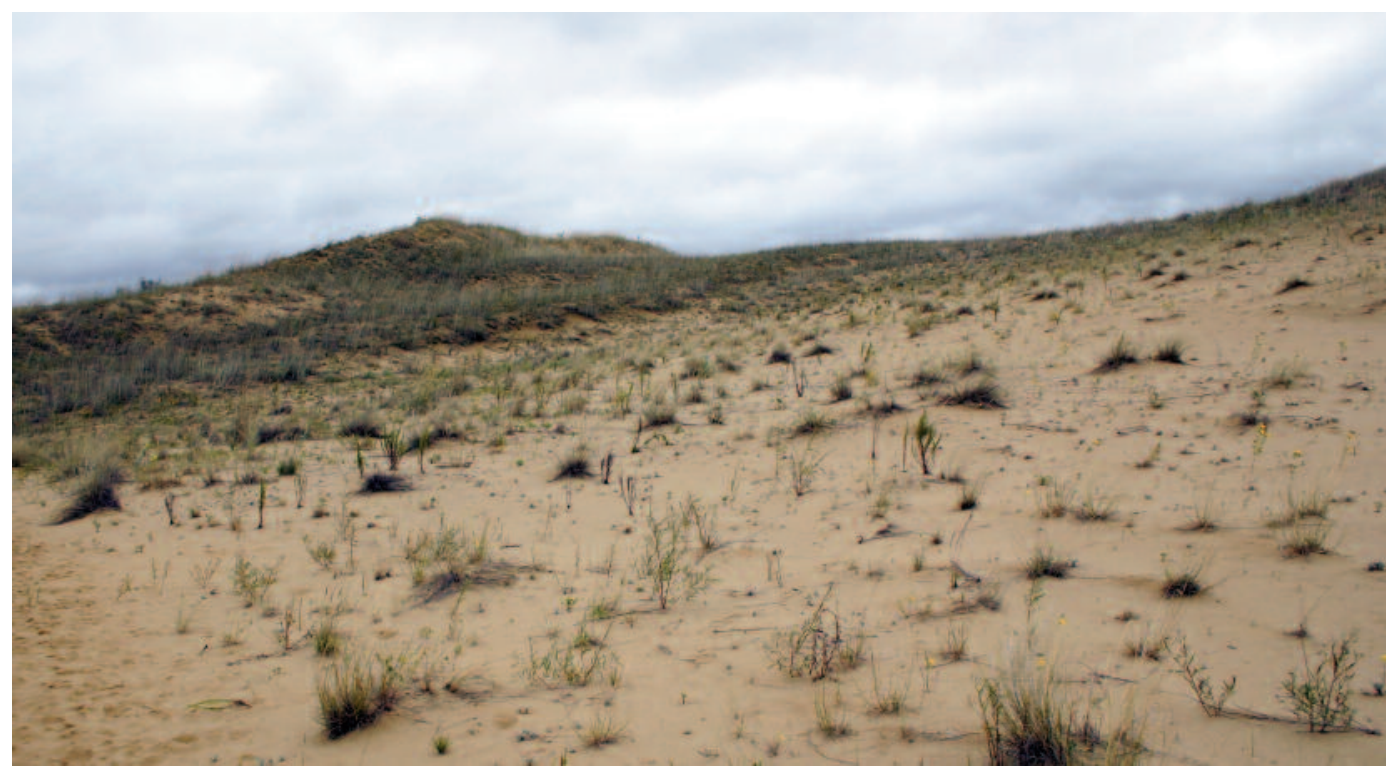

FIGURE 1. Habitat of Hooker's Bugseed, Corispermum hookeri var. hookeri, on a sand dune in Spruce Woods Provincial Park, Manitoba. Photograph by D. B. Robson.

TABLE 3. Bugseed (Corispermum spp.) habitat types at each Canadian locality.

\begin{tabular}{|c|c|c|c|c|c|c|c|}
\hline \multirow[b]{2}{*}{ Habitat type } & \multicolumn{5}{|c|}{$\begin{array}{c}\text { Species } \\
\text { \# localities }\end{array}$} & \multirow[b]{2}{*}{ C. sp. } & \multirow[b]{2}{*}{ Total } \\
\hline & $\begin{array}{c}C . \\
\text { americanum }\end{array}$ & $\begin{array}{c}C . \\
\text { hookeri }\end{array}$ & $\begin{array}{c}C . \\
\text { ochotense }\end{array}$ & $\begin{array}{c}C . \\
\text { pallasii }\end{array}$ & $\begin{array}{c}C . \\
\text { villosum }\end{array}$ & & \\
\hline \multicolumn{8}{|l|}{ Natural areas } \\
\hline Inland active sand dunes $\&$ blowouts & 19 & 11 & 1 & 1 & 10 & 10 & 52 \\
\hline Lacustrine beaches \& dunes & 3 & 4 & 3 & 5 & 11 & 3 & 29 \\
\hline Riparian sand banks \& dunes & 4 & 4 & 1 & 1 & 10 & 1 & 21 \\
\hline Inland sandy hills \& cliffs & 5 & 3 & & 6 & 5 & 1 & 20 \\
\hline Inland sandy plains & 3 & & & 5 & 7 & 1 & 16 \\
\hline Riparian sandbars & 1 & 4 & & 3 & 1 & 2 & 11 \\
\hline \multicolumn{8}{|l|}{ Anthropogenically impacted areas } \\
\hline Sandy roadsides & 8 & 3 & 2 & 3 & 4 & 2 & 22 \\
\hline Railways & 3 & 1 & & 7 & 9 & & 20 \\
\hline Sandy disturbed areas & 9 & 3 & 1 & 3 & 3 & 1 & 20 \\
\hline Sand and gravel pits & 5 & 1 & & & 3 & & 9 \\
\hline Cultivated fields & 3 & & & 1 & 2 & 2 & 8 \\
\hline Sandy fireguards & 1 & & & 1 & 1 & & 3 \\
\hline No habitat description & 8 & 5 & & 10 & 12 & 6 & 41 \\
\hline
\end{tabular}

is common in the U.S., extending from Washington south to California and east to Texas, Ohio, Kentucky and Arkansas (NatureServe 2010*).

Pallas Bugseed (C. pallasii) is native to Russia, Mongolia and China, and introduced in Europe (Welsh et al. 2003). Its distribution also spans widely across Canada in six ecozones but is less abundant than Hairy and American Bugseed (Figure 5). It has been found only as far north as Bonnyville, Alberta, just west of Cold Lake. In the U.S. Pallas Bugseed has been found only in Michigan, North Dakota and Ohio: it appears to be extirpated in Missouri (NatureServe 2010*).

Hooker's Bugseed is found in six ecozones and six provinces/territories (Figure 6). This species appears to be endemic to Canada as no specimens from the U.S. have been documented yet (NatureServe 2010*). A unique variety of Hooker's Bugseed, var. pseudodeclinatum Mosyakin, has been found near Burnaby and in the Okanagan of British Columbia; no other specimens possess seeds that are two times as long as broad 


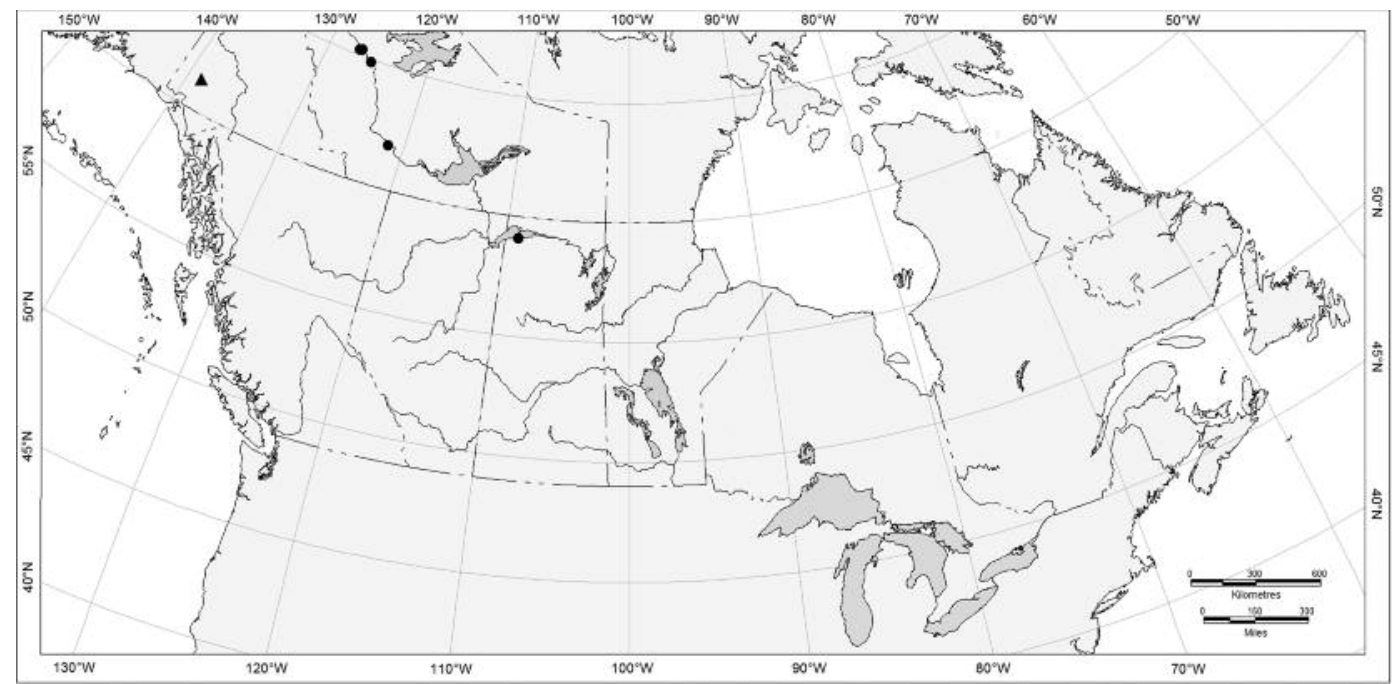

FIGURE 2. Distribution map of Alaskan Bugseed, Corispermum ochotense var. ochotense (circles) and C. o. var. alaskanum (triangle), in Canada based on Canadian herbarium specimens.

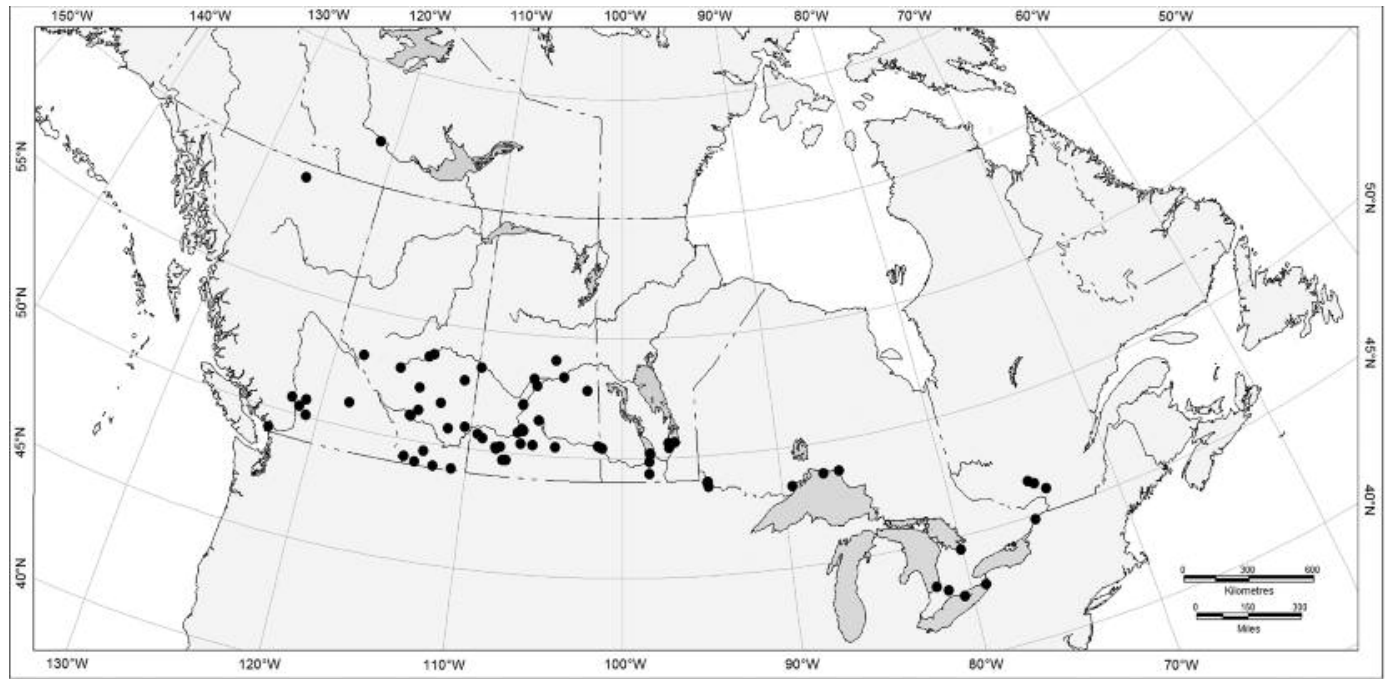

FIGURE 3. Distribution map of Hairy Bugseed, Corispermum villosum in Canada based on Canadian herbarium specimens.

(Mosyakin 1995). However this designation is based on only two specimens: the holotype, collected in 1965 from Burnaby Lake and the paratype, collected from Quilchena in 1906. Since no recent specimens of this taxon have been obtained, the validity of this designation is somewhat questionable as the specimens could just represent unusual plants rather than entire populations; additional specimens of Bugseed from these localities are needed to illuminate the issue. Unfortunately, as land use in southwestern B.C. has changed dramatically since the type specimens were collected, the existence of appropriate habitat at present is unknown.

\section{Status of the bugseeds in Canada}

The most frequently collected species in Canada is Hairy Bugseed followed closely by American Bugseed. Pallas Bugseed is less common but its status is uncertain as it may be at least partly introduced to North America from Europe (Welsh et al. 2003). Further study of this species is needed to determine whether it is native, exotic or possibly both. In Welsh et al. 


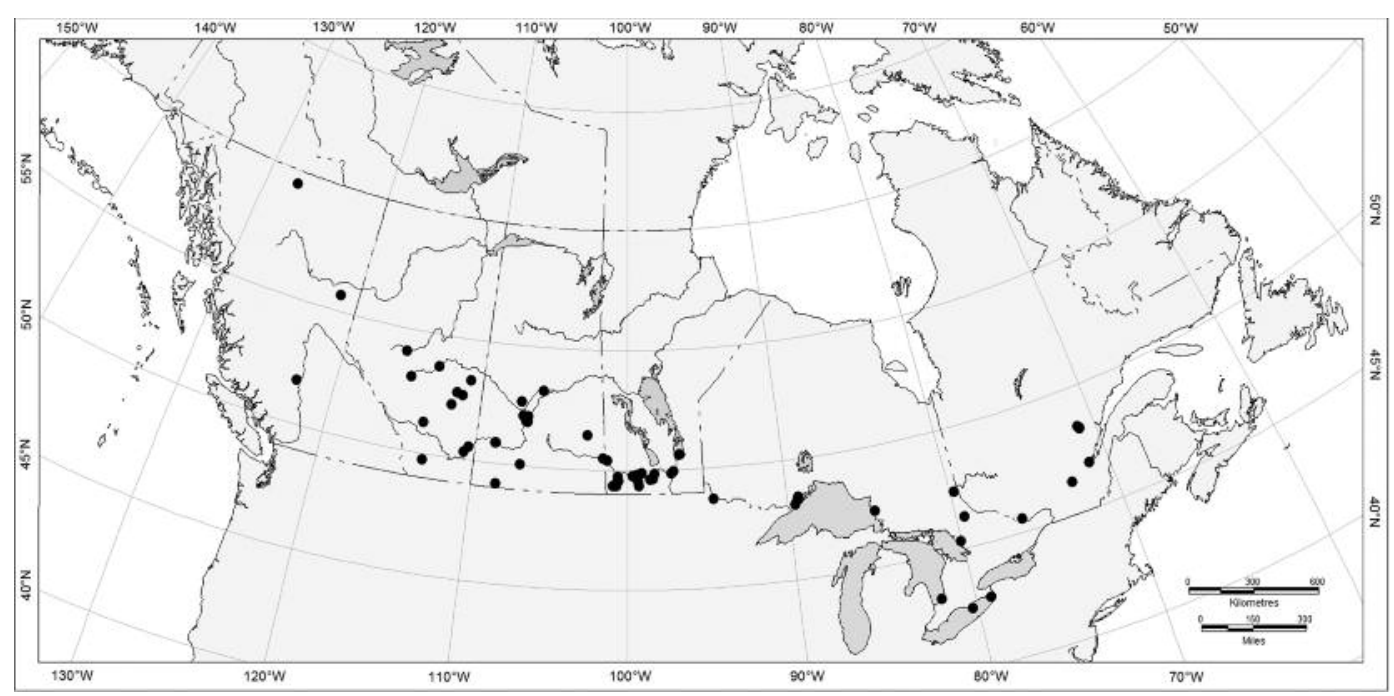

FIgURE 4. Distribution map of American Bugseed, Corispermum americanum, in Canada based on Canadian herbarium specimens.

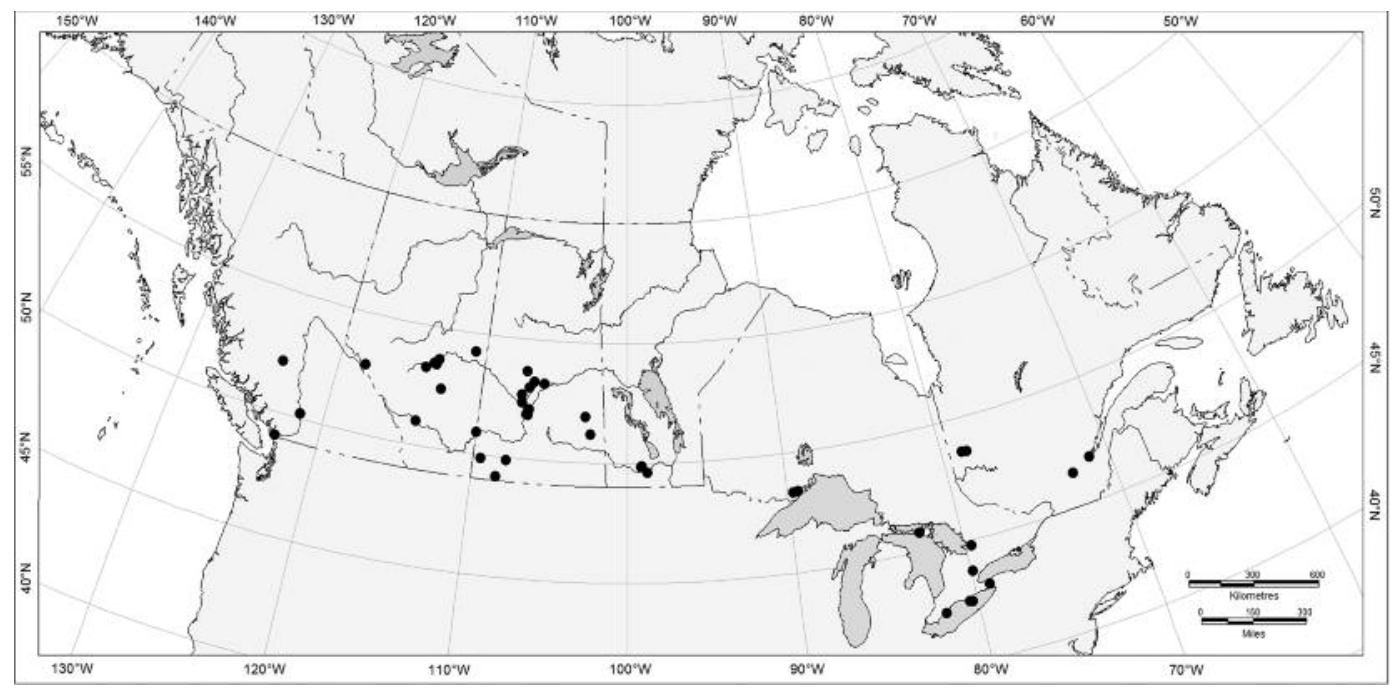

FIgURE 5. Distribution map of Pallas Bugseed, Corispermum pallasii, in Canada based on Canadian herbarium specimens.

(2003) it was postulated that Hooker's Bugseed was introduced to Ontario from western Canada. However, the presence of Hooker's Bugseed in natural lacustrine beaches and dunes in the Great Lakes region rather than anthropogenically disturbed ones along roadsides and railways, suggests that it is more likely native to Ontario. Alaskan Bugseed is the rarest species; it has only been found at eight localities in Canada. However, as it occurs in areas that are seldom visited by botanists, it may be more widespread.
None of the Bugseed taxa are currently candidates for Committee on the Status of Endangered Wildlife in Canada (2010*) status. However, most Canadian Bugseed taxa have rare National General Status (CESCC $\left.2005^{*}\right)$ and NatureServe ranks $(2010 *)$ in the jurisdictions where they occur. Several omissions were identified during the herbarium specimen review: NatureServe $\left(2010^{*}\right)$ has not ranked Pallas Bugseed in Alberta, Saskatchewan or Quebec, nor Hairy Bugseed in Alberta, Saskatchewan or Northwest Territories even 


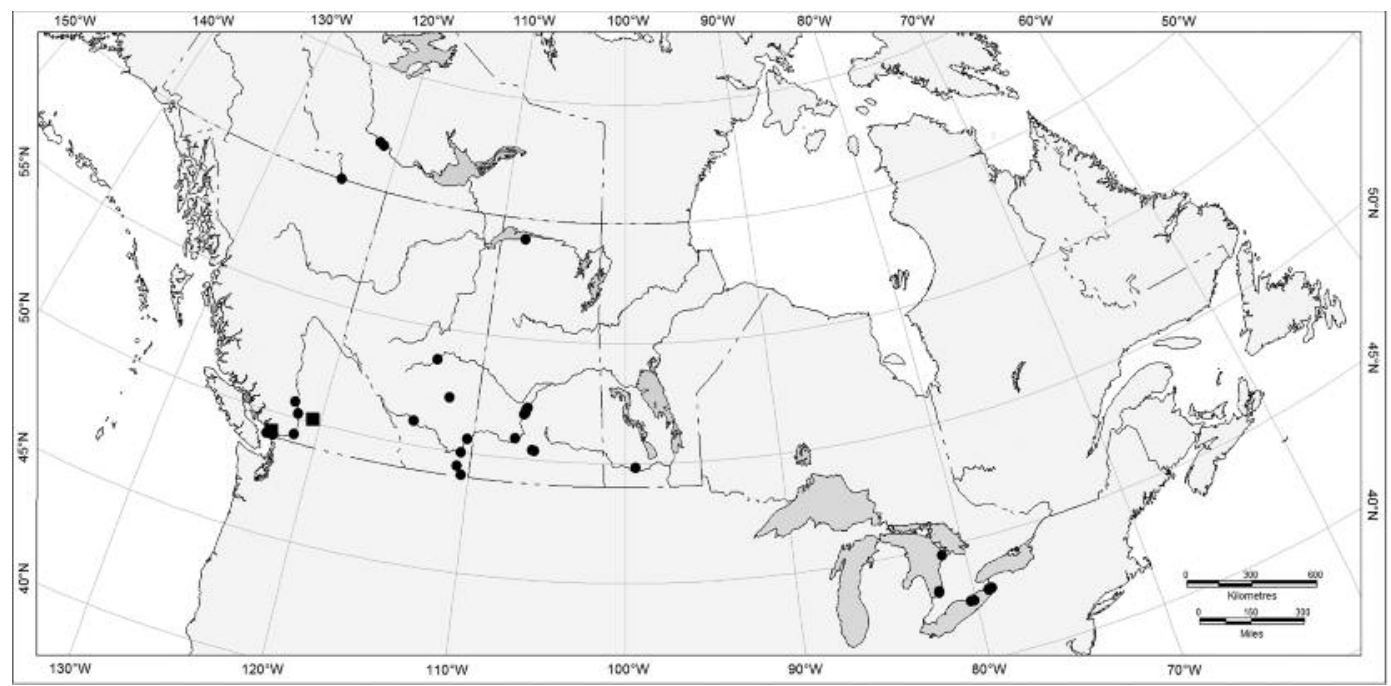

FIGURE 6. Distribution map of Hooker's Bugseed, Corispermum hookeri var. hookeri (circles) and C. h. var. pseudodeclinatum (squares), in Canada based on Canadian herbarium specimens.

though their occurrence has been documented in these jurisdictions in various publications (Mosyakin 1995; Cody et al. 2003; Harms 2003; Welsh et al. 2003; Cayoutte and Dalpé 2007). Further, there is no National General Status rank for Pallas Bugseed or Hairy Bugseed in Alberta (2005*). In several other cases taxa have uncertain or undetermined ranks (CESCC 2006*; NatureServe $2010^{*}$ ) due to the lack of data on the species in that jurisdiction. This is understandable since, of the Bugseed herbarium specimens examined, only $27 \%$ of them were collected since 1970 . To address these inaccuracies suggested ranks for Bugseed taxa in Canada were made (Table 4). One problem in particular is the "Exotic" rank given to American Bugseed in British Columbia (CESCC 2006*). Since all three specimens of American Bugseed found in British Columbia are from remote, natural habitats rather than urban, anthropogenically disturbed areas where species introductions typically occur, this designation is most likely wrong. Thus the recommended rank for American Bugseed in British Columbia is "May Be At Risk" or "Critically Imperilled". The Bugseed populations found in Quebec are a bit of an enigma; although most recent records are from anthropogenically impacted areas, there are a few records of plants on natural riparian sand bars along the St. Lawrence River as far back as 1932. Whether the Bugseed species found in Quebec are indeed "native" to that province or were introduced from farther west is difficult to say without more recent specimen records. Therefore I ranked the Quebec taxa as "Undetermined" or "Uncertain" until additional information is available, rather than "Exotic" as this term implies that the species in native to another country.

\section{Discussion}

The broad distribution pattern of Canadian bugseeds suggests that they are less influenced by factors such as temperature, moisture, day length and average autumnal frost dates than by substrate, occurring primarily where there are course-textured bare or moderately disturbed soils present. However, they are likely intolerant of high salinity as no plants were found on oceanic beaches. Although Alaskan Bugseed is restricted to areas north of the $59^{\text {th }}$ parallel in Canada, it also occurs broadly in northern Asia so its distribution is also wide (Mosyakin 1995). There is a certain amount of distributional overlap with two, three and even four Bugseed species being observed in some localities. Whether the niches of the species at these localities overlap completely, or are slightly different is unknown and needs further research. Bugseed species may hybridize with each other in areas of distributional overlap as several of Mosyakin's annotation labels indicated the existence of some intermediate specimens. However, natural interspecific hybridization in annual plants is thought to be relatively rare due to frequent sterility of the seeds (Solbrig 1970), although there are exceptions (Rieseberg 1997). An examination of the genetic profile of Bugseed plants may be useful in determining whether hybrids are currently produced, and whether some North American species arose from hybrid origins.

Plant competition is relatively low in sand dune habitats due to limited resources, recurrent disturbances, and drastic fluctuations in temperature and moisture availability (Perumal and Maun 2006). The adaptations that allow plants to survive under such harsh conditions do not enable them to thrive in habitats that are less stressful, where plant competition is more intense 
TABle 4. Suggested national and subnational NatureServe, 2010* (NS) and Canadian Endangered Species Conservation Council, 2005* (CC) status ranks for Canadian Bugseed (Corispermum) taxa based on a herbarium specimen review.

\begin{tabular}{|c|c|c|c|c|c|c|c|c|c|c|c|c|c|c|c|c|c|c|}
\hline \multirow[b]{3}{*}{ Species } & \multicolumn{18}{|c|}{ Proposed Status Ranks ${ }^{1}$} \\
\hline & \multicolumn{2}{|c|}{ Canada } & \multicolumn{2}{|c|}{$\mathrm{BC}$} & \multicolumn{2}{|c|}{$\mathrm{AB}$} & \multicolumn{2}{|c|}{ SK } & \multicolumn{2}{|c|}{$\mathrm{MB}$} & \multicolumn{2}{|c|}{$\mathrm{ON}$} & \multicolumn{2}{|c|}{ QU } & \multicolumn{2}{|c|}{ NT } & \multicolumn{2}{|c|}{ YT } \\
\hline & $\mathrm{NS}^{2}$ & $\mathrm{CC}^{3}$ & NS & $\mathrm{CC}$ & NS & $\mathrm{CC}$ & NS & $\mathrm{CC}$ & NS & $\mathrm{CC}$ & NS & $\mathrm{CC}$ & NS & $\mathrm{CC}$ & NS & $\mathrm{CC}$ & NS & $\mathrm{CC}$ \\
\hline C. americanum & 3 & 3 & 1 & 2 & 2 & 2 & 3 & 3 & 3 & 3 & 3 & 3 & $\mathrm{U}$ & 5 & - & - & - & - \\
\hline C. hookeri & 3 & 3 & 2 & 2 & 2 & 2 & 2 & 2 & 1 & 2 & 2 & 2 & - & - & 1 & 2 & - & - \\
\hline v. hookeri & 3 & 3 & 2 & 2 & 2 & 2 & 2 & 2 & 1 & 2 & 2 & 2 & - & - & 1 & 2 & - & - \\
\hline v. pseudodeclinatum & 1 & 2 & 1 & 2 & - & - & - & - & - & - & - & - & - & - & - & - & - & - \\
\hline C. ochotense & 2 & 2 & - & - & - & - & 1 & 2 & - & - & - & - & - & - & 2 & 2 & 1 & 2 \\
\hline v. ochotense & 2 & 2 & - & - & - & - & 1 & 2 & - & - & - & - & - & - & 2 & 2 & - & - \\
\hline v. alaskanum & 1 & 2 & - & - & - & - & - & & - & - & - & - & - & - & - & - & 1 & 2 \\
\hline C. pallasii & 3 & 3 & 1 & 2 & 2 & 2 & 3 & 3 & 1 & 2 & 2 & 2 & $\mathrm{U}$ & 5 & - & - & - & - \\
\hline C. villosum & 3 & 3 & 2 & 2 & 3 & 3 & 3 & 3 & 2 & 2 & 2 & 2 & $\mathrm{U}$ & 5 & 1 & 2 & - & - \\
\hline
\end{tabular}

${ }^{1}$ Proposed status using NatureServe, 2010* (NS) and Canadian Endangered Species Conservation Council 2005* (CC) ranks.

${ }^{2}$ Key to NatureServe Status Ranks

$1=$ Critically Imperilled

2 Imperilled

$3=$ Vulnerable

$\mathrm{U}=$ Uncertain

${ }^{3}$ Key to Canadian Endangered Species Conservation Council Status Ranks

1 = At Risk (protected by Species at Risk Act 2002, or listed by Committee on the Status of Endangered Wildlife in Canada or a provincial governing body)

2 = May Be At Risk

$3=$ Sensitive

$5=$ Undetermined

(Grime 2001; Perumal and Maun 2006). A study on the sand dune successional gradient at Lake Michigan dunes recorded the presence of American bugseeds only on the more open foredunes and secondary dunes, not the more heavily vegetated savanna nearby (LeichtYoung et al. 2009). In fact, Bugseed seeds are susceptible to damping off fungi when grown in moister, loamy soils rich in organic matter (Van Asdall and Olmstead 1963); this may explain why bugseeds, despite their annual habit, have not become major agricultural weeds in fertile Canadian croplands.

Mosyakin (1995) postulates that bugseeds likely migrated from Asia into North America along three paleo-migration routes along the Bering Land bridge approximately 38000 years before present. As the glaciers melted, the barren lands would have been colonized by annual, psammophilic pioneer plants like bugseeds. Since then new species of bugseeds evolved in North America resulting in the present compliment of species. Some psammophilic species are now becoming rare due to the loss of sand dune complexes (Robson 2006). The oscillation of lake levels and impact of severe storms has resulted in the loss and alteration of lacustrine dune habitats (Maun 1989). Dune stabilization has been documented as occurring in the Great Lakes region and the Prairies likely due in part to the suppression of wildfires (Hugenholtz and Wolfe 2005; Catling et al. 2008). Dune stabilization over the last 50 years in the Prairie ecozone where most Bugseed populations are found has resulted in the loss of $50 \%$ to $90 \%$ of the active sand surface (Hugenholtz and Wolfe 2005; Robson 2006). However, climate models suggest that increasing evapotranspiration in the prairies due to climate change could increase dune activity, especially if there are severe and prolonged droughts (Wolfe and Thorpe 2005). This report provides important historical information for determining the status of these plants as habitats change in the future.

The results of this study show that the status ranks for bugseeds in Canada are in need of revision and status recommendations are made based on the number of historical localities. However, information on whether the population size of and habitat for a taxon is declining is also required for status assessment (NatureServe 2010*). Given the loss of dune habitats and alteration of land use that has occurred in the last several decades, there is a strong need for field studies where these historical populations of bugseeds are revisited to determine if they are still extant and if so, what the population size is. As several other sand dunes species, including Smooth Goosefoot (Chenopodium subglabrum (S. Wats.) A. Nels.), Hairy Prairie Clover (Dalea villosa (Nutt.) Spreng. var. villosa), Small-flowered Sand-verbena (Tripterocalyx micranthus (Torr.) Hook.), Tiny Cryptanthe (Cryptantha minima Rydb.) and Western Spiderwort (Tradescantia occidentalis (Britt.) Smyth are already protected under the Species at Risk Act 2002 due to the documented decline in sand dune habitat, bugseeds are likely threatened by similar factors. The main difference between the already listed rare dune plants and bugseeds is that 
the former mainly grow on inland or riparian dunes in the prairies while the latter are also capable of growing in lacustrine dunes and some anthropogenically disturbed sites. However, records of bugseeds that were found on anthropogenically disturbed sites were often several decades old. As exotic plant species have come to dominate anthropogenically disturbed sites, native ruderals may not be as common in these areas as before. Once again revisitation to historical localities is needed to determine current status. A complicating factor is that since annual psammophilic species typically experience population fluctuations (Li et al. 2005; Robson 2006) multiple visits may be required to determine the presence or absence of these taxa. Taxa most in need of assessment include the Canadian endemic Hooker's Bugseed and the northern Alaskan Bugseed. Collecting further information on these taxa will help scientists determine if any are in need of protection under the Species at Risk Act 2002.

\section{Acknowledgments}

Financial support for this research was received from The Manitoba Museum Foundation Inc. Thanks are extended to Jacques Cayouette at the Agriculture \& Agri-Food Canada Vascular Plant Herbarium for sending me his information on Corispermum in Quebec. Vernon Harms graciously reviewed an earlier version of this manuscript. Collections at the following herbaria were examined: University of British Columbia (UBC), Royal British Columbia Museum (V), University of Alberta (ALTA), University of Calgary (UAC), Royal Alberta Museum (RAB), University of Regina (USAS), University of Saskatchewan (SASK), University of Manitoba (WIN), The Manitoba Museum (MMMN), Royal Ontario Museum (ROM), University of Guelph (OAC), University of Western Ontario (UWO), University of Waterloo (WAT), University of Toronto (TRTE), Agriculture \& Agri-Food Canada Vascular Plant Herbarium (DAO), Canadian Museum of Nature (CAN), University of Montreal (MT), McGill University (MTMG), University of Laval (QFA) and the Government of Quebec (QUE).

\section{Documents Cited (marked * in text)}

Canadian Endangered Species Conservation Council (CESCC). 2006. Wild Species 2005: The General Status of Species in Canada. Available at: http://www.wildspecies. ca/wildspecies2005/GS2005_site_e.pdf (accessed October 2010).

Committee on the Status of Endangered Wildlife in Canada (COSEWIC). 2010. Candidate Wildlife Species. Canadian Wildlife Service, Environment Canada, Ottawa. Available http://www.cosewic.gc.ca/eng/sct3/index_e.cfm (accessed October 2010).

NatureServe. 2010. NatureServe Explorer: An online encyclopedia of life [web application]. Version 6.0. NatureServe, Arlington, Virginia. Available http://www.nature serve.org/explorer (accessed September 2010).
Government of Canada. 2002. Species at Risk Act 2002 Bill $\mathrm{C}-5$, an act respecting the protection of wildlife species at risk in Canada. Available http://www.parl.gc.ca/37/2/parl bus/chambus/house/bills/government/C-5/C-54/C-5TOCE .html (accessed October 2010).

\section{Literature Cited}

Betancourt, J. L., A. Long, D. J. Donahue, A. J. Jull, and T. H. Zabel. 1984. Pre-Columbian age for North American Corispermum L (Chenopodiaceae) confirmed by accelerator radiocarbon dating. Nature 311: 653-655.

Catling, P. M., H. Goulet, and B. Kostiuk. 2008. Decline of two open Champlain sea dune systems in eastern Ontario and their characteristic and restricted plants and insects. Canadian Field-Naturalist 122: 99-117.

Cayouette, J., and Y. Dalpé. 2007. Découverte de quatre espèces d'intérêt en Mauricie. Flora Quebeca 12: 9-11.

Cody, W. J., K. L. Reading, and J. M. Line. 2003. Additions and range extensions to the vascular plant flora of the continental Northwest Territories and Nunavut, Canada II. Canadian Field-Naturalist 117: 448-465.

Grime, J. P. 2001. Plant strategies, vegetation processes, and ecosystem properties, $2^{\text {nd }}$ edition. John Wiley \& Sons, Rexdale.

Harms, V. L. 2003. Checklist of the vascular plants of Saskatchewan and the provincially and nationally rare native plants in Saskatchewan. University Extension Press, Saskatoon.

Hugenholtz, C. H., and S. A. Wolfe. 2005. Recent stabilization of active sand dunes on the Canadian prairie and relation to recent climate variations. Geomorphology 68: 131147.

Leicht-Young, S. A., N. B. Pavlovic, R. Grundel, and K. J. Frohnapple. 2009. A comparison of seed banks across a sand dune successional gradient at Lake Michigan dunes (Indiana, USA) Plant Ecology 202: 299-308.

Li, F.-R., L.-Y. Zhao, X.-Y. Zhao, T.-H. Zhang, and G. Li. 2005. The relative importance of pre- and post-germination determinants for recruitment of an annual plant community on moving sandy land. Annals of Botany 96: 1215-1223.

Looman, J., and K. F. Best. 1979. Budd's flora of the Canadian Prairie Provinces. Canadian Government Publishing Centre, Supply and Services Canada, Hull.

Maihle, N. J., and W. H. Blackwell, Jr. 1978. A synopsis of North American Corispermum (Chenopodiaceae). Sida 7: 382-391.

Marshall, I. B., and P. H. Schut. 1999. A national ecological framework for Canada. Ecosystems Science Directorate, Environment Canada and Research Branch, Agriculture and Agri-food Canada, Ottawa, Ontario.

Matthews, J. V., C. E. Schweger, and O. L. Hughes. 1990. Plant and insect fossils from the May Indian village section (central Yukon): new data on middle Wisconsinan environments and glaciation. Geographie physique et Quaternaire 44: 15-26.

Maun, M. A. 1989. Population biology of Ammophila breviligulata and Calamovilfa longifolia on Lake Huron sand dunes. III. Dynamic changes in plant community structure. Canadian Journal of Botany 67: 1267-1270.

Moss, E. H. 1983. Flora of Alberta ( $2^{\text {nd }}$ edition by J. G. Packer). University of Toronto Press, Toronto.

Mosyakin, S. L. 1995. New taxa of Corispermum L. (Chenopodiaceae), with preliminary comments on the taxonomy of the genus in North America. Novon 5: 340-353. 
Perumal, V. J. and M. A. Maun. 2006. Ecopysiological response of dune species to experimental burial under field and controlled conditions. Plant Ecology 184: 89-104.

Rieseberg, L. H. 1997. Hybrid origins of plant species. Annual Review of Ecology and Systematics 28: 359-389.

Robson, D. B. 2006. A conservation evaluation of smooth goosefoot, Chenopodium subglabrum (Chenopodiaceae), in Canada. Canadian Field Naturalist 120: 335-341.

Scoggan, H. J. 1956. Flora of Manitoba. National Museum of Canada, Ottawa.

Scoggan, H. J. 1978. The Flora of Canada. National Museum of Canada, Ottawa.

Solbrig, O. T. 1970. Principles and methods of plant biosystematics. The Macmillan Company, Toronto.

Sukhorukov, A. P. 2007. Fruit anatomy and its taxonomic significance in Corispermum (Corispermoideae, Chenopodiaceae). Willdenowia 37: 63-87.
Van Asdall, W., and C. E. Olmstead. 1963. Corispermum hyssopifolium on the Lake Michigan dunes it community and physiological ecology. Botanical Gazette 124: 155172.

Welsh, S. L., C. W. Crompton, and S. E. Clemants. 2003. Chenopodiaceae. Pages 258-404 in Flora of North America, volume 4, Magnoliophyta: Caryophyllidae, part 1. Edited by Flora of North America Editorial Committee. Oxford University Press, New York.

Wolfe, S., and J. Thorpe. 2005. Shifting sands: climate change impacts on sand hills in the Canadian prairie and implications for land use management. Prairie Forum 30: 123-142.

Received 12 October 2010

Accepted 29 October 2010 